Jurnal PenKoMi: Kajian Pendidikan \& Ekonomi

Journal Hompage: http://jurnal.stkipbima.ac.id/index.php/PK/index

\title{
PENGARUH GAYA KEPEMIMPINAN TERHADAP MOTIVASI BERPRESTASI PEGAWAI KANTOR DINAS KEPENDUDUKAN DAN PENCATATAN SIPIL KOTA BIMA
}

\author{
Akhyar $^{1}$, Muhammad Iptidaiyah ${ }^{2}$ \\ ${ }^{1,2}$,Sekolah Tinggi Ilmu Sosial dan Ilmu Politik Mbojo Bima
}

Email: akhyarstisip@gmail.com¹, muhamad.iptidaiyah@stisipbima.ac.id ${ }^{2}$,

\begin{tabular}{ll}
\hline Info Artikel & Abstrak \\
\hline & Tujuan penelitian ini adalah untuk mengetahui pengaruh Gaya \\
Keywords: & Kepemimpinan Terhadap Motivasi Berprestasi Pegawai Kantor Dinas \\
Gaya & Kependudukan dan Pencatatan Sipil (Dukcapil) Kota Bima. Penelitian \\
Kepemimpinan, & ini menggunakan pendekatan kuantitatif. Desain penelitian dalam \\
Motivasi Berprestasi & penelitian ini merupakan penelitian explanatory research yaitu jenis \\
& penelitian yang menjelaskan kausal atau hubungan sebab akibat \\
& antar variabel melalui pengajuan hipotesa sehingga memungkinkan \\
& diperoleh suatu kesimpulan. Pupulasi dalam penelitian ini adalah \\
& seluruh pegawai yang ada di dinas Dukcapil Kota Bima berjumlah \\
& 80 orang. Adapun teknik pengumpulan data menggunakan \\
& observasi dan kuesioner/angket. Sementara teknik analisis data \\
& dengan pendekatan kuantitatif melalui teknik analisis regresi \\
& sederhana, dengan tahapan analisis, yaitu: uji validitas, uji reliabilitas, \\
& analisa regresi linier sederhana, dan uji hipotesis (uji t). Hasil \\
& penelitian menunjukkan bahwa gaya kepemimpinan memiliki \\
& pengaruh positif terhadap motivasi berprestasi pegawai, dengan \\
& sumbangsih pengaruh sebesar $86,3 \%$, sedangkan sisanya 13,7\% \\
& dipengaruhi oleh faktor lain diluar variabel penelitian ini. \\
\hline
\end{tabular}

\section{PENDAHULUAN}

Sumber daya manusia (SDM) merupakan salah satu penentu keberhasilan suatu organisasi, baik organisasi swasta maupun pemerintah. Peran SDM dalam merencanakan, melaksanakan, serta mengendalikan berbagai kegiatan operasional organisasi sangat menentukan kemajuan organisasi (Ardana, dkk 2013). Pengelolaan SDM yang efektif dan efisien dapat mendorong optimalisasi kinerja pegawai/karaywan organisasi. Kinerja organisasi ditentukan oleh faktor SDM yang berkualitas. Apabila kinerja karyawan (pegawai) rendah, maka akan menjadi hambatan perusahaan atau oraganisasi dalam mencapai tujuannya (Ardana, dkk 2013). Hal tersebut membuat organisasi melakukan beberapa kegiatan seperti merekrut, menyeleksi, melatih, dan mempertahankan pegawai/karyawan yang berkualitas dan memiliki kinerja yang optimal. Oleh karenanya, kepemimpinan menjadi salah satu varibel yang menentukan kinerja setiap anggota organisasi. Seorang pemimpin diharapkan mampu mempengaruhi bawahannya untuk melaksanakan tugas yang diperintahkan tanpa paksaan, sehingga bawahan secara 


\section{"Jurnal PenKoMi : Kajian Pendidikan dan Ekonomi" Vol. 4, No. 2 Juni 2021 e-ISSN: 2614-6002}

sukarela akan berperilaku dan berkinerja sesuai tuntutan organisasi melalui arahan pimpinannya. Pemimpin harus mampu membangkit motivasi dan meningkatkan profesionalitas dari para bawahannya, agar mau bekerja sesuai dengan apa yang ingin dicapai, mampu menciptakan visi dan lingkungan yang memotivasi para bawahan untuk berprestasi.

Finch \& McGough (Usman 2010) mengatakan bahwa tugas umum seorang pemimpin adalah memberikan pengarahan atau bimbingan. Salah satu bentuk pengarahan yang dilakukan oleh seorang pemimpin adalah memotivasi bawahan. Motivasi adalah salah satu alat atasan agar bawahan mau bekerja keras dan bekerja cerdas sesuai dengan yang diharapkan (Usman, 2010). Lebih lanjut, menurut Rivai \& Sagala (2013) motivasi adalah serangkaian sikap dan nilai-nilai yang mempengaruhi individu untuk mencapai hal yang spesifik sesuai dengan tujuan individu. Menurut Muslih (2012) motivasi mempunyai peran sangat penting bagi karyawan atau para pemimpin, karena dengan adanya motivasi yang tinggi akan berdampak pada pekerjaan yang dilakukan dengan bersemangat dimana akan dapat dicapai kinerja yang tinggi dan tentunya akan mendukung tercapainya tujuan yang diinginkan secara efisien dan efektif.

Dengan memperhatikan penjelasan di atas, maka dapat disimpulkan bahwa motivasi merupakan dorongan yang berasal dari dalam maupun luar diri seorang individu untuk menghasilkan output guna mencapai tujuan yang ditentukan. Adanya motivasi kerja yang dimiliki oleh karyawan/pegawai dalam bekerja akan membuat karyawan dapat menghasilkan kinerja yang sesuai dengan ekspektasi perusahaan guna membantu perusahaan mencapai tujuan mereka. Motivasi sangat penting bagi manajer untuk meningkatkan kinerja (performance) bawahannya karena kinerja tergantung dari motivasi, kemampuan dan lingkungannya (Usman, 2010).

Berdasarkan hasil observasi dan studi pendahuluan yang dilakukan penulis menunjukkan bahwa motivasi berprestasi pegawai secara umum masih rendah. Di Dinas Kependudukan dan Pencatatan Sipil (Dukcapil) Kota Bima sendiri, masalah motivasi berprestasi masih rendah, masih terdapat pegawai yang tidak disiplin, bersikap pasif terhadap perubahan, kurang memiliki inisiatif dan masih rendahnya inovasi dalam bekerja. Meski demikian, ada juga sebagian pegawai yang memiliki motivasi berprestasi dan, yang ditunjukkan dengan profesionalitas kerja yang tinggi, memiliki prestasi kerja, dan mendapat penghargaan dari pimpinan yaitu kesempatan untuk dipromosikan ke jenjang yang lebih tinggi.

Motivasi berprestasi dikalangan pegawai menjadi penting mengingat tantangan reformasi birokrasi semakin meningkat. Oleh karenanya, peran seorang pemimpin sangat dibutuhkan dalam mendorong pegawai/bawahan untuk berprestasi. Pemimpin sebagai orang yang bertanggung jawab terhadap semua bawahannya (pegawai) harus memiliki langkah-langkah yang efektif serta program strategis lainnya yang dapat mendorong peningkatan motivasi berperastasi pegawai. Keinginan untuk meraih prestasi mutlak dimiliki setiap orang, beragam cara yang ditempuh seseorang untuk menggapainya. Semakin tinggi prestasi yang diinginkan maka semakin keras pula usaha yang harus ia keluarkan. McClelland (Rivai \& Sagala, 2013) dalam hal ini mengembangkan suatu bentuk motivasi yaitu motivasi berprestasi. Motivasi berprestasi 


\section{"Jurnal PenKoMi : Kajian Pendidikan dan Ekonomi" Vol. 4, No. 2 Juni 2021 e-ISSN: 2614-6002}

ini kebutuhan yang diperoleh sejak kecil dan terus dikembangkan pada saat seseorang menginjak kedewasaan. Pentingnya motivasi berprestasi akan menumbuhkan sikap yang positif bagi manusia. Saking termotivasinya seseorang pada suatu prestasi, ia akan selalu menerima dengan senang respon atau nasihat dan saran tentang cara meningkatkan prestasinya.

McClelland (Rivai \& Sagala, 2013) mengemukakan bahwa individu mempunyai cadangan energi potensial yang dapat dilepaskan atau dikembangkan tergantung pada dorongan motivasi individu, serta didukung oleh situasi dan kesempatan yang tersedia. Dengan demikian, motivasi untuk mengerahkan cadangan energy potensial tersebut menurut McClelland terpusat pada tiga bentuk kebutuhan, yaitu: (1) kebutuhan akan prestasi (need of achievement) disingkat nAch, (2) kebutuhan akan kekuasaan (need of power) disingkat nPow, dan (3) kebutuhan akan afiliasi (need of affiliation) disingkat nAff. Kepemimpinan merupakan aspek penting yang mendorong pegawai untuk meningkatkan kinerja dan meraih prestasi. Yukl (2010: 75) menyatakan kepemimpinan dipandang sangat penting karena dua hal: Pertama, adanya kenyataan bahwa penggantian pemimpin seringkali mengubah kinerja suatu unit, instansi atau organisasi; kedua, hasil penelitian yang menunjukkan bahwa salah satu faktor internal yang mempengaruhi keberhasilan organisasi adalah kepemimpinan, mencakup proses kepemimpinan pada setiap jenjang organisasi, kompetensi dan tindakan pemimpin yang bersangkutan.

Gaya kepemimpinan menentukan kinerja suatu anggota organisasi. Sementara kinerja ditentukan oleh motivasi berprestasi yang dimiliki oleh setiap anggota organisasi. Penelitian Koech, P.M. \& Namusonge, G.S (2012) menunjukkan bahwa ada hubungan antara gaya kepemimpinan transformasional dan peringkat kinerja organisasi yang tinggi $(0,518-0,696, \mathrm{P}<0,05)$, sedangkan korelasi antara perilaku kepemimpinan transaksional dan kinerja organisasi relatif rendah $(0,219-0,375, \mathrm{P}<0,05)$. Seperti yang diharapkan, gaya kepemimpinan laissez faire tidak signifikan berkorelasi dengan kinerja organisasi. Berdasarkan hasil penelitian tersebut, dapat ditegaskan bahwa manajer harus meninggalkan gaya kepemimpinan laissez faire, pemimpin harus lebih terlibat dalam membimbing bawahan mereka; manajer harus merumuskan dan menerapkan reward \& recognition sistem yang efektif. Selain itu, hasil penelitian merekomendasikan bahwa manajer harus berusaha memberikan contoh model peran untuk bawahan mereka, menginspirasi bawahan untuk terus menjadi lebih baik dengan memberikan makna dan menantang untuk bekerja dengan kualitas yang tinggi, merangsang bawahan untuk menjadi lebih inovatif dan kreatif serta memperhatikan kebutuhan masing-masing individu untuk tumbuh dan berprestasi.

Berdasarkan hasil observasi dan studi pendahuluan terhadap beberapa penelitian di atas maka, maka tujuan penelitian ini adalah untuk mengetahui pengaruh Gaya Kepemimpinan Terhadap Motivasi Berprestasi Pegawai Kantor Dinas Kependudukan dan Pencatatan Sipil (Dukcapil) Kota Bima. 


\section{"Jurnal PenKoMi : Kajian Pendidikan dan Ekonomi" Vol. 4, No. 2 Juni 2021 e-ISSN: 2614-6002}

\section{METODE PENELITIAN}

Penelitian ini menggunakan pendekatan kuantitatif. Desain penelitian dalam penelitian ini merupakan penelitian explanatory research yaitu jenis penelitian yang menjelaskan kausal atau hubungan sebab akibat antara variabel melalui pengajuan hipotesa sehingga memungkinkan diperoleh suatu kesimpulan. Pupulasi dalam penelitian ini adalah seluruh pegawai yang ada di dinas Dukcapil Kota Bima berjumlah 80 orang. Sampel penelitian diambil sebanyak 80 orang. Arikunto (2010) mengatakan bahwa apabila subjek penelitian kurang dari 100 orang lebih baik diambil semuanya sehingga penelitian adalah penelitian populasi, akan tetapi bila subjeknya lebih dari 100 orang, maka diperbolehkan untuk mengambil sampel 10$15 \%$ atau 20-25\% atau lebih sesuai dengan kemampuan yang dimiliki peneliti, baik dana, waktu maupun tenaga. Teknik pengambilan sampel dalam penelitian ini menggunakan metode sensus sampel jenuh. Menurut Sugiyono (2016) sampling jenuh adalah teknik penentuan sampel bila semua anggota populasi digunakan sebagai sampel. Adapun teknik pengumpulan data yang digunakan, yaitu: (1) Observasi, pada tahap ini peneliti melakukan pengamatan secara langsung ke lokasi penelitian untuk mendapatkan gambaran tentang masalah yang diteliti, sehingga peneliti melakukan penjelajahan umum dan menyeluruh, melakukan deskripsi terhadap semua yang dilihat, didengar, dan dirasakan; (3) Kuesioner, yaitu dengan menyediakan sejumlah pertanyaan tertulis dengan pilihan jawaban menggunakan skala likert. Responden dapat memilih jawaban yang telah disediakan sesuai dengan yang dialami oleh responden. Pilihan jawaban pada angket meliputi: sangat setuju (SS), setuju (S), ragu-ragu (RR), tidak setuju (TS), dan sangat tidak setuju (STS). Teknik analisis data dengan pendekatan kuantitatif melalui teknik analisis regresi sederhana, dengan tahapan analisis, yaitu: uji validitas, uji reliabilitas, analisa regresi linier sederhana, dan uji hipotesis (uji t).

\section{HASIL DAN PEMBAHASAN}

\section{Deskripsi Data Hasil Penelitian}

\section{Deskripsi Responden}

Responden yang menjadi obyek penelitian ini yaitu berdasarkan kuesioner yang telah disebar kepada 80 orang pegawai Dukcapil Kota Bima. Penyajian data mengenai identitas responden dimaksudkan untuk memberikan gambaran tentang keadaan responden, meliputi: jenis kelamin, umur, pendidikan dan lama bekerja.

\section{a. Karakteristik Responden berdasarkan Jenis Kelamin}

Berdasarkan data-data yang di dapat dari daftar pernyataan yang ada pada kuesioner, dapat dilihat pada tabel mengenai jenis kelamin dari pegawai Dukcapil Kota Bima sebagai berikut:

Tabel 4.1 Karakteristik Responden Berdasarkan Jenis Kelamin

\begin{tabular}{|l|c|c|}
\hline \multicolumn{1}{|c|}{ Jenis Kelamin } & Jumlah (orang) & Persentase (\%) \\
\hline Laki-laki & 56 & $70 \%$ \\
\hline Perempuan & 24 & $30 \%$ \\
\hline Jumlah & 80 & $100 \%$ \\
\hline
\end{tabular}

Sumber: Data Dokumen diolah, 2021. 


\section{"Jurnal PenKoMi : Kajian Pendidikan dan Ekonomi" Vol. 4, No. 2 Juni 2021 e-ISSN: 2614-6002}

Berdasarkan tabel 4.1 diatas, maka dapat diketahui bahwa sebagian besar responden berjenis kelamin laki-laki yaitu sebesar 56 orang atau $70 \%$ dan responden perempuan sebesar 24 orang atau $30 \%$.

\section{b. Karakteristik Responden Berdasarkan Usia}

Berdasarkan hasil penelitian yang telah dilakukan maka dapat diketahui bahwa usia pegawai terlihat pada tabel berikut ini:

Tabel 4.2. Karakteristik Responden Berdasarkan Usia

\begin{tabular}{|l|l|l|}
\hline \multicolumn{1}{|c|}{ Usia } & \multicolumn{1}{|c|}{ Jumlah (orang) } & \multicolumn{1}{c|}{ Persentase (\%) } \\
\hline 21-30 Tahun & 49 & $61 \%$ \\
\hline 31-40 Tahun & 21 & $26 \%$ \\
\hline 41-50 Tahun & 10 & $13 \%$ \\
\hline Jumlah & 80 & $100 \%$ \\
\hline
\end{tabular}

Sumber: Data Dokumen diolah, 2021.

Berdasarkan tabel 4.2 diatas, jumlah responden kelompok umur 21-30 tahun sebesar 49 orang atau 61\%, responden kelompok umur 31-40 tahun sebesar 21 orang atau $26 \%$ dan responden dikelompok umur 41-50 tahun sebesar 10 orang atau 13\%. Sebagian besar responden berumur 21-30 tahun 49 orang 61 .

\section{c. Karakteristik Responden Berdasarkan Pendidikan}

Berdasarkan data-data yang didapat dari daftar pernyataan pada kuesioner, dapat dilihat tabel mengenai tingkat pendidikan dari responden sebagai berikut:

Tabel 4.3 Karakteristik Responden Berdasarkan Pendidikan

\begin{tabular}{|l|c|c|}
\hline \multicolumn{1}{|c|}{ Pendidikan } & Jumlah (orang) & Persentase (\%) \\
\hline SMA/SMK/Sederajat & 5 & $6,25 \%$ \\
\hline S1 & 70 & $87,5 \%$ \\
\hline S2 & 5 & $6,25 \%$ \\
\hline Jumlah & 80 & $100 \%$ \\
\hline
\end{tabular}

Sumber: Data Dokumen diolah, 2021.

Berdasarkan tabel 4.3 diatas, diketahui responden yang berpendidikan SMA/SMK/Sederajat sebesar 5 orang atau 6,25 \%, responden yang berpendidikan S1 sebanyak 70 atau sebesar 87,5\%, dan S2 sebesar 5 orang atau 6,25\%. Sebagian besar responden mempunyai tingkat pendidikan $\mathrm{S} 1$.

\section{d. Karakteristik Responden Berdasarkan Lama Bekerja}

Berdasarkan data yang didapat dari daftar pernyataan dalam kuesioner, mengenai lama responden bekerja dapat ditunjukkan pada tabel berikut:

Tabel 4.4 Karakteristik Responden Berdasarkan Lama Bekerja

\begin{tabular}{|l|c|c|}
\hline \multicolumn{1}{|c|}{ Lama Bekerja } & Jumlah (Orang) & Persentase (\%) \\
\hline 1-5 Tahun & 42 & $53 \%$ \\
\hline 6-10 Tahun & 28 & $35 \%$ \\
\hline 11-15 Tahun & 10 & $13 \%$ \\
\hline Jumlah & 80 & $100 \%$ \\
\hline
\end{tabular}

Sumber: Data Dokumen diolah, 2021. 


\section{"Jurnal PenKoMi : Kajian Pendidikan dan Ekonomi" Vol. 4, No. 2 Juni 2021 e-ISSN: 2614-6002}

Berdasarkan tabel 4.4 diatas, responden bekerja selama 1-5 tahun sebesar 42 orang atau 53\%, responden bekerja selama 6-10 tahun sebesar 28 orang atau $35 \%$, responden bekerja selama 11-15 tahun sebesar 10 orang atau 13\%. Sebagian besar responden sudah bekerja selama 1-5 tahun sebesar 42 orang atau 53.

\section{Deskripsi Data Setiap Variabel Penelitian}

a. Deskripsi Tanggapan Pegawai Tentang Gaya Kepemimpinan (X)

Tanggapan pegawai tentang gaya kepemimpinan (X) pada dinas Dukcapil Kota Bima dapat disajikan pada tabel 4.5 sebagai berikut:

Tabel 4.5 Tanggapan Pegawai Tentang Gaya Kepemimpinan (X)

\begin{tabular}{|c|l|c|}
\hline No & \multicolumn{1}{|c|}{ Pernyataan } & Mean \\
\hline 1 & Memberikan contoh kepada bawahan & 3,38 \\
\hline 2 & Menginspirasi bawahan untuk maju & 4,00 \\
\hline 3 & Merangsang bawahan untuk menjadi lebih inovatif dan kreatif & 3,60 \\
\hline 4 & $\begin{array}{l}\text { Memperhatikan kebutuhan masing-masing individu bawahan } \\
\text { untuk tumbuh dan berprestasi. }\end{array}$ & 3,94 \\
\hline 5 & Menerapkan reward dan punishment & 3,58 \\
\hline Mean & $\mathbf{3 , 7 9}$ \\
\hline
\end{tabular}

Sumber: Data Angket diolah, 2021.

Berdasarkan tabel 4.5 tersebut dapat digambarkan bahwa tanggapan pegawai terhadap variabel gaya kepemimpinan $(X)$ dengan rata-rata skor sebesar 3,79. Nilai ini termasuk dalam rentang kategori "baik", yang artinya sebagian besar responden beranggapan bahwa Gaya Kepemimpinan di Dukcapil Kota Bima sudah baik.

\section{b. Deskripsi Tanggapan Pegawai Tentang Motivasi Beprestasi (Y)}

Tanggapan pegawai tentang Motivasi Berprestasi (Y) pada dinas Dukcapil Kota Bima dapat disajikan pada tabel 4.6 berikut:

Tabel 4.6 Tanggapan Pegawai Tentang Motivasi Berprestasi (Y)

\begin{tabular}{|c|l|c|}
\hline No & \multicolumn{1}{|c|}{ Pernyataan } & Mean \\
\hline 1 & Pegawai memiliki antusias tinggi dalam melaksanakan tugas & 4,45 \\
\hline 2 & Pegawai selalu menyelesaikan tugas tepat waktu & 3,95 \\
\hline 3 & $\begin{array}{l}\text { Pegawai terampil dalam melaksanakan pekerjaan sesuai } \\
\text { dengan tugas dan fungsi }\end{array}$ & 3,75 \\
\hline 4 & $\begin{array}{l}\text { Pegawai selalu menyelesaikan tugas sesuai dengan kualitas } \\
\text { yang diinginkan ditentukan }\end{array}$ & 3,98 \\
\hline 5 & Pegawai menyelesaikan pekerjaan dengan ketelitian yang tinggi & 3,79 \\
\hline 6 & Pegawai selalu bekerja mengikuti prosedur atau ketentuan & 3,86 \\
\hline Mean & $\mathbf{3 , 9 6}$ \\
\hline
\end{tabular}

Sumber: Data Angket diolah, 2021.

Berdasarkan tabel 4.6 tersebut dapat digambarkan bahwa tanggapan pegawai terhadap variabel motivasi berprestasi (Y) dengan rata-rata skor 3,96. Nilai ini termasuk dalam rentang kategori "baik", yang artinya sebagian besar pegawai sudah mempunyai kinerja yang baik, tinggal ditingkatkan lagi. 


\section{"Jurnal PenKoMi : Kajian Pendidikan dan Ekonomi" Vol. 4, No. 2 Juni 2021 e-ISSN: 2614-6002}

\section{Analisis Data Hasil Penelitian}

\section{a. Uji Validitas}

Menurut Arikunto (2010) validitas adalah suatu ukuran yang menunjukkan tingkat-tingkat kevalidan atau kesahihan sesuatu instrumen. Uji validitas dilakukan dengan mengkorelasikan setiap skor indikator dengan total skor item dalam setiap variabel secara statistic, hasil dari korelasi tersebut dinamakan korelasi product moment ( $\mathrm{r}$ hitung). Bila korelasi tiap indikator positif dan besarnya 0,3 ke atas, maka merupakan konstruk yang kuat. Jadi dapat disimpulkan bahwa instrumen tersebut memiliki validitas konstruksi yang baik dan dengan membandingkannya dengan $\mathrm{r}$ tabel didapat dengan menggunakan tabel $\mathrm{r}$ product moment yaitu menentukan $\mathrm{n}$ (sampel) $=80-2=78$ dengan sig. $\alpha=0,05$ sehingga didapat $\mathrm{r}$ tabel sebesar 0,219. Ketentuannya apabila nilai $r$ hitung lebih besar diabanding $r$ tabel maka indikator atau kuesioner dapat dikatakan valid.

\section{b. Uji Reliabilitas}

Uji reliabilitas digunakan untuk melihat tingkat kehandalan indikator atau kuesioner apabila digunakan kembali sebagai alat ukur variabel. Pengujian dilakukan dengan membandingkan nilai alpha cronbach's variabel standar 0,6. Jika nilai alpha melebihi 0,6 maka indikator atau kesioner dinyatakan reliabel. Hasil uji reliabilitas dapat dilihat pada tabel berikut:

Tabel 4.7 Hasil Uji Reliabilitas

\begin{tabular}{|l|l|l|}
\hline Variabel & Nilai Alpha & Keterangan \\
\hline Gaya Kepemimpinan (X) & 0.824 & Reliabel \\
\hline Motivasi Berprestasi (Y) & 0.813 & Reliabel \\
\hline
\end{tabular}

Sumber: Data Angket diolah, 2021.

Berdasarkan tabel diatas bahwa variabel bebas yaitu gaya kepemimpinan (X), dan variabel terikat yaitu motivasi berprestasi (Y) masing-masing memiliki nilai alpha cronbach yang lebih besar 0,6. Kondisi ini menunjukkan bahwa seluruh variabel tersebut reliabel dan dapat digunakan pada analisis selanjutnya.

\section{c. Analisis Regresi Linear Sederhana}

Analisis regresi linear sederhana digunakan untuk mengetahui besarnya pengaruh variabel bebas (independen) terhadap variabel terikat melalui suatu persamaan regresi sederhana. Berdasarkan perhitungan dengan menggunakan program SPSS versi 20 diperoleh persamaan regresi sebagai berikut ini:

Coefficients $^{\mathrm{a}}$

Tabel 4.8 Model Persamaan Regresi

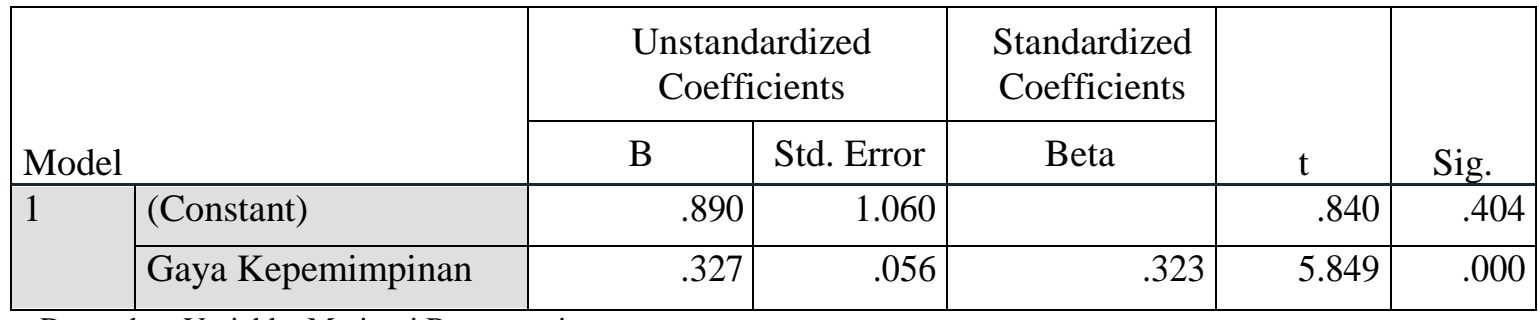

a. Dependent Variable: Motivasi Berprestasi

Sumber: Data Angket Hasil Olah SPSS versi 20, 2021. 


\section{"Jurnal PenKoMi : Kajian Pendidikan dan Ekonomi" Vol. 4, No. 2 Juni 2021 e-ISSN: 2614-6002}

Berdasarkan tabel diatas, maka persamaan regresi yang terbentuk pada uji regresi ini adalah sebagai berikut:

$$
\begin{aligned}
& Y=a+b X \\
& Y=0,890+0,327 X
\end{aligned}
$$

Model tersebut dapat diinteprestasikan sebagai berikut:

a. Konstanta (a) sebesar 0,890 memberi arti apabila variabel bebas (Gaya Kepemimpinan) adalah konstan, maka besarnya variabel terikat yaitu motivasi berprestasi adalah bernilai sebesar 0,890 satuan.

b. Gaya kepemimpinan (X) memiliki nilai koefisien sebesar 0,327. Hal ini menandakan bahwa koefisien variabel gaya kepemimpinan (X) memiliki pengaruh positif (searah) terhadap motivasi berprestasi (Y). Artinya semakin tinggi nilai gaya kepemimpinan, maka semakin tinggi nilai motivasi berprestasi pegawai

Jadi, variabel bebas yakni gaya kepemimpinan memiliki pengaruh yang positif terhadap variabel terikat yakni motivasi berprestasi. Untuk menafsirkan tingkat koefisien korelasi dilakukan dengan kriteria sebagai berikut :

Tabel 4.9 Tabel Interval Koefisien Korelasi

\begin{tabular}{|c|c|}
\hline Interval Koefisien & Tingkat Hubungan \\
\hline $0,00-0,199$ & Sangat Rendah \\
\hline $0,20-0,399$ & Rendah \\
\hline $0,40-0,599$ & Sedang \\
\hline $0,60-0,799$ & Kuat \\
\hline $0,80-1,000$ & Sangat Kuat \\
\hline
\end{tabular}

Sumber: Sugiyono (2011).

Hasil analisis regresi berganda diatas didapatkan nilai koefisien korelasi berganda (R) sebesar 0.929, hal ini menunjukkan bahwa antar variabel bebas dan variabel terikat memiliki tingkat hubungan dalam kategori sangat kuat. Adapun nilai koefisien determinasi $\left(\mathrm{R}^{2}\right)$ didapatkan sebesar 0,863 sebesar $86,3 \%$. Artinya bahwa variabel bebas mempunyai pengaruh terhadap variabel terikat sebesar $86,3 \%$, sedangkan sisanya $13,7 \%$ dipengaruhi oleh faktor lain diluar variabel penelitian ini.

\section{Uji t}

Uji t digunakan untuk mengetahui pengaruh variabel bebas $(\mathrm{X})$ terhadap variabel terikat Kinerja karyawan (Y). Adapun kiteria yang digunakan adalah:

Jika $t_{\text {hitung }}<$ atau sig $>0,05$ maka Ho diterima, $\mathrm{H}_{1}$ ditolak

Jika $t_{\text {tabel }}>$ atau sig $<0,05$ maka Ho ditolak, $\mathrm{H}_{1}$ diterima

Nilai $\mathrm{t}_{\text {tabel }}$ pada tingkat $\alpha=5 \%$ atau 0,05 dan derajat bebas $(\mathrm{df})=\mathrm{n}-\mathrm{k}-1=80-3-1$ $=76$, maka diperoleh nilai $\mathrm{t}_{\text {tabel }} 1,665$.

Adapun hasil analisis uji t dengan menggunakan program SPSS versi 20, maka didapatkan hasil sebagai berikut: 
Coefficients $^{\mathbf{a}}$

Tabel 4.10 Hasil Uji-t

\begin{tabular}{|l|l|r|r|}
\hline \multicolumn{2}{|l|}{ Model } & \multicolumn{1}{c|}{ T } & \multicolumn{1}{c|}{ Sig } \\
\hline \multirow{2}{*}{1} & (Constant) & .840 & .404 \\
\cline { 2 - 4 } & Gaya Kepemimpinan & 5.849 & .000 \\
\hline
\end{tabular}

a. Dependent Variable: Motivasi Berprestasi

Sumber: Data Angket Hasil Olah SPSS versi 20, 2021.

Berdasarkan dari pada tabel diatas didapatkan nilai $t_{\text {hitung }}$ untuk variabel Gaya kepmimpinan sebesar 5,849 dengan tingkat signifikan sebesar 0,000. Oleh karena itu nilai $t_{\text {hitung }}(5,849)>$ dari $t_{\text {tabel }}(1,665)$ dan nilai signifikan yang dihasilkan sebesar 0,000 yang lebih kecil dari 0,05 maka Ho ditolak dan $\mathrm{H}_{1}$ diterima. Artinya bahwa variabel bebas gaya kepemimpinan (X) secara mempunyai pengaruh yang signifikan terhadap variabel terikat Motivasi Berprestasi Pegawai (Y).

\section{Pembahasan}

Berdasarkan hasil penelitian diketahui bahwa gaya kepemimpinan (X) mempunyai hubungan yang erat dengan motivasi berprestasi (Y) pada pegawai dinas Dukcapil Kota Bima. Gaya kepemimpinan mempunyai kontribusi yang besar dalam mempengaruhi peningkatan maupun penurunan motivasi berprestasi pegawai. Yukl (2010) mengemukakan bahwa kepemimpinan mencerminkan asumsi bahwa kepemimpinan berkaitan dengan proses yang disengaja dari seseorang untuk menekankan pengaruhnya yang kuat terhadap orang lain untuk membimbing, membuat struktur, memfasilitasi aktivitas dan hubungan di dalam kelompok atau organisasi. Hemphill \& Coons (Yukl, 2010) menyatakan bahwa kepemimpinan adalah perilaku individu yang mengarahkan aktivitas kelompok untuk mencapai sasaran bersama.

Hasil penelitian ini menegaskan bahwa variabel kepemimpin menentukan maju mundurnya suatu organisasi. Kepemimpinan merupakan hal yang wajib dimiliki oleh seorang pemimpin. Hal ini dikarenakan kepemimpinan adalah kemampuan yang dimiliki oleh seseorang untuk mempengaruhi orang lain agar dapat bekerja guna mencapai tujuan dan sasaran (Handoko, 2011). Menurut Wicaksono (2014) gaya kepemimpinan adalah pola tingkah laku yang dilakukan dengan mengintegrasikan tujuan organisasi dengan tujuan individu untuk mencapai tujuan yang diinginkan. Seorang pemimpin di dalam memimpin pasti memiliki gaya kepemimpinan yang sesuai dengan situasi dan kondisi karyawan yang dipimpinnya. Kemudian, menurut Indrayanto et al. (2013) kepemimpinan merupakan proses yang menginspirasi pengikut untuk terlibat, berkomitmen, dan memiliki visi serta tujuan bagi organisasi mereka, mendorong pengikut menjadi inovatif didalam memecahkan masalah organisasi, dan mendukung pengikut untuk memiliki kompetensi dalam kepemimpinan melalui pembinaan dan pengawasan. Jadi, berdasarkan penjelasan di atas dapat ditegaskan bahwa gaya kepemimpinan merupakan kemampuan yang penting untuk dimiliki oleh seorang pemimpin didalam memimpin suatu organisasi. 


\section{"Jurnal PenKoMi : Kajian Pendidikan dan Ekonomi" Vol. 4, No. 2 Juni 2021 e-ISSN: 2614-6002}

\section{KESIMPULAN}

Berdasarkan hasil penelitian, maka dapat disimpulkan bahwa gaya kepemimpinan memiliki pengaruh positif terhadap motivasi berprestasi pegawai pada dinas Dukcapil Kota Bima, dengan sumbangsih pengaruh sebesar 86,3\%, sedangkan sisanya $13,7 \%$ dipengaruhi oleh faktor lain diluar variabel penelitian ini.

\section{DAFTAR PUSTAKA}

Ardana, Komang., Mujiati, Ni Wayan dan A.A Ayu Sriathi. 2013. Buku Ajar Perilaku Keorganisasian. Denpasar: Fakultas Ekonomi Universitas Udayana.

Arikunto, Suharsimi. 2010. Prosedur Penelitian: Suatu Pendekatan Praktek, Jakarta: Rineka Cipta.

Handoko, T. Hani. 2011. Manajemen. Yogyakarta: BPFE - Yogyakarta.

Hersey, P. \& Blanchard, P. 2000. Manajemen Perilaku Organisasi yang Memanfaatkan Sumber Daya Manusia. Edisi ke-9 dalam Bahasa Indonesia. London: PrenticeHall.

Indrayanto, A., John, B., Kandy, B., dan Noermijati. 2013. "A case study of transformational leadership and para - police performance in Indonesia." Policing: An International Journal of Police Strategies and Management. Vol. 37. No. 2. pp 373 - 388. Emerald Insight.

Koech, P.M. \& Namusonge, G.S. 2012. "The Effect of Leadership Styles on Organizational Performance at State Corporations in Kenya". International Journal of Business and Commerce. Vol. 2, No.1. PP 1-12.

Muslih, B. 2012. Analisis Pengaruh Motivasi terhadap Kepuasan kerja dan KinerjaPegawai diPT. Sang Hyang Seri (Persero) Regional III Malang. Jurnal Aplikasi Manajemen. Vol.10. No. 4. ISSN : 1693 - 5241.

Rivai, V \& Sagala, E.J. 2013. Manajemen Sumber Daya Manusia untuk Perusahaan dari Teori ke Praktik. Jakarta: PT RajaGrafindo Persada.

Sugiyono. 2016. Metode Penelitian Kuantitatif, kualitatif dan R\&D. Bandung: Alfabeta.

Usman, H. 2010. Manajemen: Teori, Praktek dan Riset Pendidikan. Jakarta: Bumi Aksara.

Wicaksono, Y.M. 2014. Analisis Pengaruh Gaya Kepemimpinan Transformasional, Motivasi Kerja, dan Komitmen Organisasi terhadap Kinerja Karyawan (Studi pada Pusat Koperasi Unit Desa Provinsi Jawa Timur). Diakses pada tanggal 6 Juli 2021 melalui: eprints.undip.ac.id

Yukl, G. 2010. Kepemimpinan dalam Organisasi. Edisi Indonesia. Jakarta: Penerbit PT Indeks. 